\title{
Canopy Disturbances Catalyse Tree Species Shifts in Swiss Forests
}

\author{
Daniel Scherrer, ${ }^{1 *} \odot$ Davide Ascoli, ${ }^{2} \odot$ Marco Conedera, ${ }^{3} \odot$ \\ Christoph Fischer, ${ }^{1}$ Janet Maringer, ${ }^{3} \odot$ Barbara Moser, ${ }^{1} \odot$ \\ Petia Simeonova Nikolova, ${ }^{1}$ Andreas Rigling, ${ }^{1,4} \odot$ and \\ Thomas Wohlgemuth ${ }^{1} \odot$
}

\begin{abstract}
${ }^{1}$ Swiss Federal Institute for Forest, Snow and Landscape Research WSL, Zürcherstrasse 111, 8903 Birmensdorf, Switzerland; ${ }^{2}$ Department of Agriculture, Forest and Food Sciences, University of Torino, Largo Paolo Braccini 4, Grugliasco, TO, Italy; ${ }^{3}$ Swiss Federal Institute for Forest, Snow and Landscape Research WSL, c/o Campus di Ricerca, a Ramél 18, 6593 Cadenazzo, Switzerland; ${ }^{4}$ Department of Environmental Systems Science, Institute of Terrestrial Ecosystems, ETH Zurich, Universitätstrasse 16, 8092 Zurich, Switzerland
\end{abstract}

\begin{abstract}
Widely observed inertia of forest communities contrasts with climate change projections that suggest dramatic alterations of forest composition for the coming decades. Disturbances might be a key process to catalyse changes in tree species composition under environmental change by creating opportunities for 'new' species to establish. To test this assumption, we compared two assessments (1993-1995, 2009-2017) from the Swiss National Forest Inventory to evaluate which forests were opened by natural canopy disturbance (that is, wind, insect outbreaks, fire and drought) and if these disturbances altered tree species composition both in terms of species-specific basal area and recruitment densities. Natural disturbances affected $14 \%$ of the Swiss forests within 25 years, with wind and insect outbreaks being the most frequent $(75 \%)$ and fire and drought being rare $(<1.5 \%)$. Disturbances led to a shift from conifer to broadleaf
\end{abstract}

Received 17 November 2020; accepted 18 April 2021; published online 26 May 2021

Supplementary Information: The online version contains supplementary material available at https://doi.org/10.1007/s10021-021-0064 9-1.

Authors Contributions TW initiated the idea and DS developed the methods; DS and CF analysed the data; DS, TW and MC led the writing of the manuscript. All authors contributed critically to the drafts and gave final approval for publication.

*Corresponding author; e-mail: daniel.scherrer@wsl.ch tree species at low elevation, in particular in dense Picea abies stands, but no change was observed at higher elevations. The composition of undisturbed sites persisted during the same period. Our results demonstrate that undisturbed forests widely resist changes in tree species composition as an effect of direct ingrowth by stand-forming species. Disturbance events seem necessary to create opportunities for climatically 'better suited and site-adapted' species to (re-)establish and therefore potentially catalyse tree species turnover under environmental changes. We detected a reduction of tree species that were-centuries ago-cultivated outside their primary natural range, in particular $P$. abies, or depended on traditional management practices (Pinus sylvestris, Castanea sativa), which may inform us on how the projected increase in disturbance frequency and severity might filter tree species composition and hereby alter forest structure.

Key words: Castanea sativa; Drought; Insect outbreaks; National forest inventory; Picea abies; Pinus sylvestris; Vegetation shift; Windthrow. 


\section{HighLIGHTS}

- Disturbances create regeneration windows for better site-adapted species.

- Post-disturbance forest dynamics reverse earlier economy-driven management.

- Low elevation spruce forests partly transform to more broadleaeved forests.

\section{INTRODUCTION}

Climate change is altering species distributions (Lenoir and others 2020) with important consequences for human well-being (Pecl and others 2017), and the continued change is expected to amplify during the century (Pereira and others 2010; Lindner and others 2014; Dyderski and others 2018). Resulting changes in forest structures and species compositions may potentially alter ecosystem processes and related services, claiming for an adaptation of management practices (Millar and others 2007; Civantos and others 2012; Brang and others 2014). Many models predict dramatic changes in tree species distributions over the coming decades (for example, elevational or latitudinal shifts of species; Gehrig-Fasel and others 2007; Dyderski and others 2018; Jandl and others 2019), altered frequencies of disturbances (Seidl and others 2017) and post-disturbance changes in vegetation (for example, as a consequence of drought-induced mortality; Allen and others 2015; McDowell and others 2020). On the other hand, representative surveys have observed only marginal changes under ongoing climate warming during the last decades (for example, Lenoir and others 2008, 2010b; Bertrand and others 2011; Küchler and others 2015; Scherrer and others 2017; Etzold and others 2019). In European forests, shifts in distribution ranges of tree species have been mostly assessed at their present latitudinal or altitudinal limits (for example, Grundmann and others 2011; Bolte and others 2014; Hernández and others 2014), with larger effects in species restricted to mountain habitats or with faster population turnover (Lenoir and others 2008; Dyderski and others 2018). This discrepancy between model simulations and recent field observations of latesuccessional species could be explained by four main factors all related to the longevity of dominant tree species: (1) slow regeneration processes due to long persistence of the optimal phase of dominant trees, high plasticity and rare mast fructification (for example, Bertrand and others 2011;
Ascoli and others 2017; Copenhaver-Parry and others 2020), (2) limited dispersal (for example, Svenning and Skov 2007; Lenoir and others 2010a), (3) limited establishment due to competition, fluctuating resource availability and forest management (for example, Bertrand and others 2016; Nikolova and others 2019; Shi and others 2020), and (4) lack of gap-creating disturbances generating opportunities for the recruitment of (new) species (Grubb 1977). All these factors hinder rapid climate-driven changes in tree species composition and thereby may contribute to an increasing amount of extinction and colonisation debt (Talluto and others 2017; Liang and others 2018). On the other hand, reports supporting rapid vegetation shifts due to climate warming often refer to opportunistic case studies and neglect the vast majority of other forests, where possible substantial changes may remain unobserved (Jump and others 2007; Brandl and others 2020).

Both simulation studies (for example, Liang and others 2018; Scherrer and others 2020) as well as forest surveys (for example, Peñuelas and Boada 2003; Rigling and others 2013; Brice and others $2019,2020)$, suggest that disturbances and extreme events (natural or anthropogenic) are a key component in facilitating forest transitions under climate change by creating favourable conditions for opportunistic species better adapted to the novel (and presumed future) climatic conditions. Whether such events that lead to tree and stand mortality, either alter tree species compositions or simply result in direct ingrowth (that is, infilling by the already dominant species; for example, Kramer and others 2014) might be highly dependent on the interaction of environmental conditions, disturbance agents and their severity (Seidl and others 2017; Jentsch and von Heßberg 2019; Nikolova and others 2019). Whether post-disturbance tree composition will change or not also depends on stand age, development stage, dominant disturbance regimes, environmental constraints (for example, high vs low elevation) and understory dynamics (prevailing ground vegetation; Bolte and others 2014).

To find evidence for representative disturbanceinduced forest changes, we used the unique nationwide data from the Swiss National Forest Inventory (NFI; Fischer and Traub 2019) covering several bioclimatic regions (that is, Jura, the Plateau, the Northern Alps, the Western and Eastern Central-Alps and the Southern Alps) and spanning an elevation range from 240 to $2400 \mathrm{~m}$ a.s.l. All main Swiss forest types are represented in this systematic inventory allowing us a statistically 
representative overview of disturbance events and tree species-specific post-disturbance dynamics, for example, changes in basal area and recruitment density over an average period of 25 -years. We focused on the four prevalent natural disturbance agents wind, insect outbreaks, forest fires and prolonged drought events that likely increase in frequency with future environmental change (Seidl and others 2017) to investigate: (1) how do natural disturbance agents differ in frequency among different biogeographic regions, climatic conditions and forest types, (2) which species were most affected by different natural disturbance agents and (3) are there any differences between pre- and post-disturbance tree species composition (adult trees and recruitment) that may suggest potential vegetation shifts?

\section{Material ANd Methods}

\section{Study Region and Climate Data}

The study area is Switzerland, encompassing a territory of $41,285 \mathrm{~km}^{2}$ of which $31.9 \%(13,169$ $\mathrm{km}^{2}$ ) is forested (Cioldi and others 2020). Forests range from about 200 to $2400 \mathrm{~m}$ a.s.l. with the lower elevations being naturally dominated by broadleaves and the higher elevations by conifers (Figure S1). Corresponding with regions and with steep elevation gradients around the Alpine arc, the climate strongly varies. In the north of the Alps, the climate is mainly influenced by the Atlantic Ocean, from where mild, humid winds blow. In ZurichAffoltern at $443 \mathrm{~m}$ a.s.l., winters are mild $\left(0.3^{\circ} \mathrm{C}\right.$ in January) and summers warm $\left(18.8^{\circ} \mathrm{C}\right.$ in July), with annual precipitation of $1054 \mathrm{~mm}$. In the south of the Alps, the climate is influenced by the Mediterranean system with temperatures $2-3{ }^{\circ} \mathrm{C}$ warmer than in the North, and annual precipitation usually exceeds $1600 \mathrm{~mm}$ (Locarno-Monti; $366 \mathrm{~m}$ a.s.l.). Central Alpine valleys are dry with nationwide lowest annual precipitation $(603 \mathrm{~mm}$, Sion; MeteoSwiss 2020). Following this climate heterogeneity, Switzerland is categorised into six biogeographic regions (Gonseth and others 2001; Figure 1).

\section{Forest Inventory Data}

We used data of the Swiss National Forest Inventory (NFI), recorded on a $1.4 \mathrm{~km} \times 1.4 \mathrm{~km}$ systematic permanent sample grid covering the whole country, during the second NFI (NFI2; 1993-1995) and the fourth NFI (NFI4; 2009-2017), respectively. Previous to analyses, we removed all plots classified as shrubland or not visited in both NFI2 and NFI4, eventually retaining the 5521 accessible forest plots. Passing from NFI2 to NFI4 the protocol of terrestrial data collection slightly changed as well as the survey period did, which switched from a three-year assessment window to a nine-yearwindow (continuous inventory since NFI4; Brändli and Hägeli 2019; Lanz and others 2019). The vast majority of Swiss forests were since centuries and still are managed following a 'close-to-nature' silvicultural approach (Spathelf and others 2015). The commandment of privileging natural tree recruitment or planting of native site-adapted species when natural regeneration is difficult is even embodied in the national forest law. Thus, about $81 \%$ of today's Swiss Forests originate from natural tree regeneration (Brändli and others 2020b) and large monoculture plantations are very rare as are non-native tree species (Table S1), which are only present on $2.4 \%$ of NFI plots and contribute less than $0.6 \%$ to the basal area of Swiss forests (Brändli and others 2020a).

A terrestrial NFI plot consists of several plot elements. Standing and lying trees are measured using two concentric circular plots $\left(500 \mathrm{~m}^{2}\right.$ and $\left.200 \mathrm{~m}^{2}\right)$. On the large plot, all trees with a diameter at breast height $(\mathrm{DBH}) \geq 36 \mathrm{~cm}$ are measured, while on the small plot also trees and shrubs with a $\mathrm{DBH} \geq 12$ $\mathrm{cm}$ and $<=35.9 \mathrm{~cm}$ are measured (Lanz and others 2019). Tree recruitment is defined as individuals $\geq 10 \mathrm{~cm}$ in height and $<=11.9 \mathrm{~cm}$ in DBH and was assessed using concentric circles with different sizes. In NFI2 two satellite plots $(10 \mathrm{~m}$ West and East of the plot centre) with two concentric circles differing in radius were used $(\mathrm{r}=1 \mathrm{~m}$ for heights $10-39 \mathrm{~cm}$ and $\mathrm{r}=2.12 \mathrm{~m}$ for heights $>=40 \mathrm{~cm}$ and $\mathrm{DBH}<=11.9 \mathrm{~cm}$; Stierlin 1994) and in NFI4 one satellite plot (10 m West of the plot centre) with four concentric circles was used $(\mathrm{r}=0.9 \mathrm{~m}$ for heights $10-39 \mathrm{~cm}$, $\mathrm{r}=1.5 \mathrm{~m}$ for heights of $40-129 \mathrm{~cm}, \mathrm{r}=2.5 \mathrm{~m}$ for heights $>=130 \mathrm{~cm}$ and $\mathrm{DBH}<=3.9 \mathrm{~cm}$ and $\mathrm{r}=4 \mathrm{~m}$ for DBH 4-11.9 cm; Düggelin and Keller 2017). We used the total available dataset, as preliminary analyses showed changes in sampling design between NFI2 and NFI4 to have no significant impact on recruitment density per hectare (Table S2). Different size of the satellite plots might impact analysis of species diversity, which, however, is not in focus of the present study. On the interpretation area of $50 \times 50 \mathrm{~m}(0.25 \mathrm{ha})$ around the plot centre disturbances and the NaiS site type (NST; ARGE Frehner and others 2020; Frey and others 2021) were determined. After estimating the extension of existing damages in the field, the disturbance agent was evaluated by interviews with 


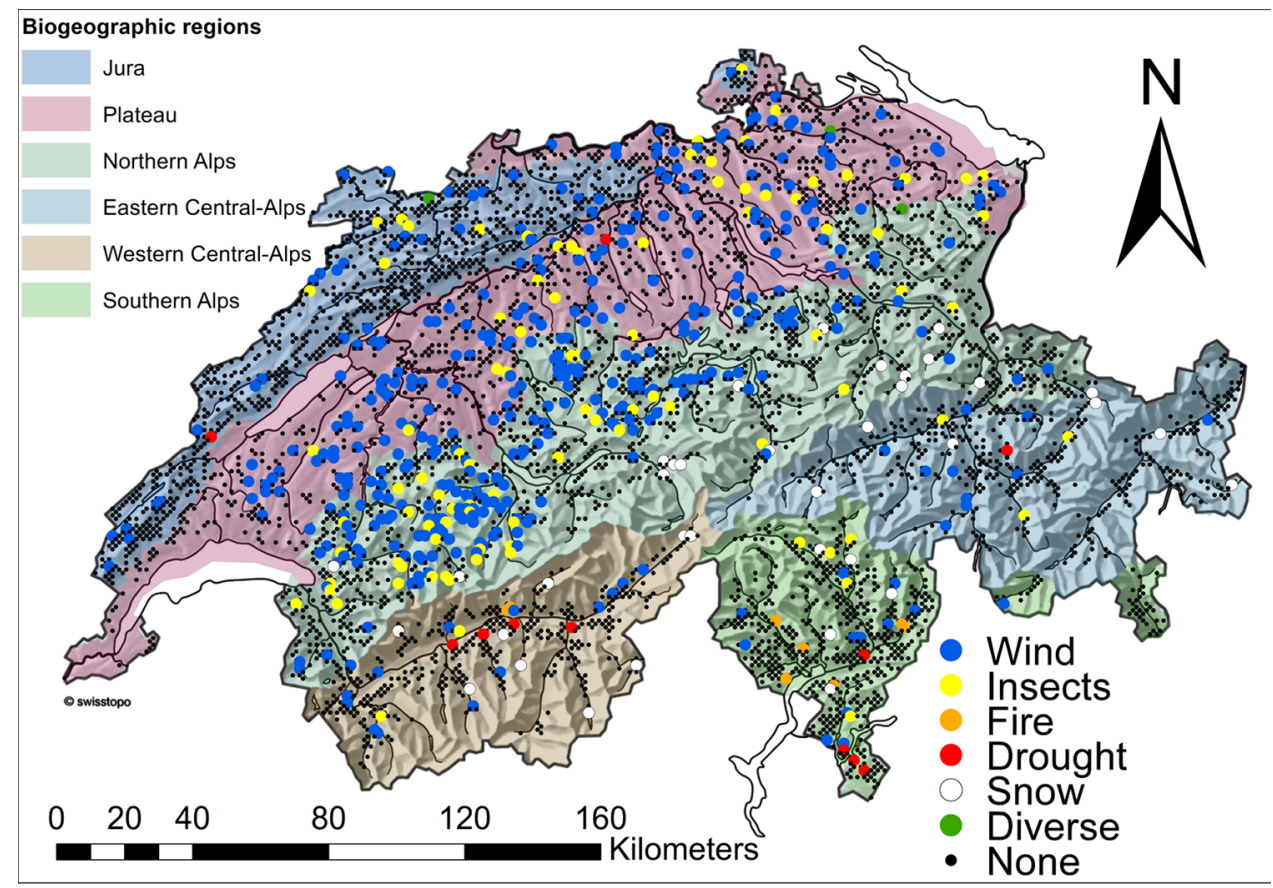

Figure 1. Biogeographic regions of Switzerland (Gonseth and others 2001) and geographic positions of NFI sample plots used in this study. Different point colours indicate the type of natural disturbance recorded in the period 1993-2017 and the shade colours different biogeographic regions. None $=$ Not naturally disturbed.

the local foresters (Stierlin 1994; Düggelin and Keller 2017). The NST was defined by experts that visited $25 \%$ of the NFI sample plots and concluded community identities by analogy (using factor maps and local knowledge) for the remaining 75\% of the plots, according to the Swiss protection forest classification (NaiS; ARGE Frehner and others 2020). Based on floristic composition, site quality and structural characteristics, NST depicts the idealised tree species composition (including recruitment) in natural forests at the optimum developmental stage, that is in balance with the dominant environmental conditions (for example, climate, topography, soil; Frey and others 2021). In this study, we used 17 aggregated NST defined according to the main tree species (for example sub-montane beech forests or sub-alpine spruce forests). We used the NST to distinguish between NFI plots hosting tree species corresponding to the natural forest vegetation from NFI plots where the current dominance of a tree species results from anthropogenic influences (for example, management or land-use history). A forest stand is then defined as natural when the occurring dominant tree species based on NFI data (that is, based on basal area) is identical to the NST (for example, Picea abies has highest basal area per ha on NFI plots belonging to the sub-alpine spruce forest NST).
However, due to present and/or past management decisions, differences may exist between the actual dominating species and the NST. To prevent confusion between dominant taxa and the NST of a NFI plot, we will use in this paper the scientific taxon name for the dominant species (for example, Picea abies, Fagus sylvatica) and the English names for the NST (for example, spruce forest and beech forest).

From roughly 300 different NFI attributes recorded on each plot, we only extracted the speciesspecific basal area of trees with $\mathrm{DBH} \geq 12 \mathrm{~cm}$ (BA, $\left.\mathrm{m}^{2} \mathrm{ha}^{-1}\right)$, the species-specific density of tree recruitment (stems ha ${ }^{-1}$ ), the damaged area per ha due to natural disturbance events $(\%)$, the natural disturbance agent, the date of the last timber harvest and the NST.

\section{Data Pre-processing}

Of the 56 tree species that were recorded in the NFI plots, only a few are very abundant and contributed to the vast bulk of biomass while the majority of species are rare or added little biomass. We, therefore, reclassified all species into twelve taxa: Abies alba (silver fir), Picea abies (spruce), Pinus cembra (Swiss stone pine), Larix spp. (larch), Pinus spp. (pine), other conifers, Castanea sativa (sweet chestnut), Fagus sylvatica (European beech), Acer 
spp. (Maple), Fraxinus spp. (ash), Quercus spp. (oak), other broadleaves (for details see Table S1). The dominant taxon for each plot was defined based on the BA represented. Further, we divided the tree recruitment into individuals with $\mathrm{DBH}<=3.9$ cm (saplings) and individuals with DBH 4-11.9 cm (pole-stage) as these size groups represent very different age cohorts and amount of (self-)thinning. While the saplings recruitment provides qualitative and quantitative information about the available species pool, the pole-stage recruitment contains information about the species that successfully established.

\section{Defining Disturbed Plots}

To distinguish between naturally disturbed NFI sample plots (hereafter called 'naturally disturbed') and all others, we used the following criteria: 'naturally disturbed' if (a) the NFI field team reported damage affecting at least $10 \%$ of the interpretation area, and (b) the local forester reported a specific disturbance agent for the plot (for example, wind, fire). Plots with a contradiction between the foresters' report and the NFI field team observations were removed from further analysis, leaving us with 5092 plots. Most of these mismatches were the result of minor disturbances already invisible at the time of the next NFI visit. In this study, we were interested in obvious, that is canopy disturbances with the potential to catalyse vegetation shifts, and consequently, these small-scale and very low-severity disturbances were not analysed. In the cases where more than a single disturbance event and/or disturbance agent affected a NFI sample plot, we determined the main disturbance agent by comparison of the area damage caused by each disturbance agent. For the later classification of plots into different disturbance agents, the main damage type (as determined by maximum area damaged) was used.

Plots without a natural disturbance event were further subdivided based on the information of the NFI into 'undisturbed' that is without any recorded natural disturbance and human intervention in the past 25 years, 'treated' that are plots where planned silvicultural treatments occurred, and 'salvage logged', which resulted from mortality/damage events related to smaller natural disturbances (that is, not recorded in the NFI). This classification allowed us to test if a larger-scale natural disturbance leads to a different vegetation trajectory compared to a human-induced disturbance (that is, 'treated' and 'salvage logged') or no intervention and no disturbance at all (that is, 'undisturbed').

\section{Data Analysis}

To test if certain site conditions (that is, biogeographic region, dominant taxa or NST) were linked to a specific natural disturbance agent, we used Chi-squared analysis. The effect of disturbance agents on the different considered taxa and the broader groups broadleaves versus conifers was analysed by comparing the absolute and relative BA changes (Wilcoxon-test). To test if and where disturbances may catalyse future vegetation shifts (that is, change in forest composition), we compared the species-specific recruitment density (for saplings and pole-stage trees) on 'naturally disturbed', 'salvage logged', 'treated' and, 'undisturbed' sites. Additionally, we used mixed-effects models to check for combined effects of site and species-specific factors on BA changes of the adult tree species and on the tree recruitment density. All statistical analyses were conducted in $\mathrm{R}$ 3.6.1 ( $\mathrm{R}$ Core Team 2020) using the packages dplyr (Wickham and others 2020) and rstatix (Kassambara 2020).

\section{RESUlts \\ Distribution of Natural Disturbance Events}

Of the 5092 NFI plots, $2024(40 \%)$ were classified as 'undisturbed', $1600(31 \%)$ as 'treated' and 778 $(15 \%)$ as 'salvage logged'. Subsequently, 690 $(14 \%)$ were classified as 'naturally disturbed' of which 411 (59\%) were disturbed by wind, 110 (16\%) by insects (predominantly bark beetle), 101 $(15 \%)$ by snow/avalanches, $8(1.2 \%)$ by fire, 11 $(1.6 \%)$ by drought and $49(7.2 \%)$ by other agents including mass movements such as landslides (39), flooding (4) and rockfall (3), phytopathogens (2) and cattle (1). Out of the 690 'naturally disturbed' plots, $163(24 \%)$ were affected by several disturbance events during the observation period (Table S3). The majority of these multiple disturbance events were combinations of wind and insects $(72 \%)$ in which usually a wind disturbance favoured an insect outbreak a few years later. Another notable source of multiple disturbances was snow and drought, which both reoccurred in at same plots over the years.

Natural disturbance events were significantly more frequent in the 'Plateau' and the 'Northern Alps' and less frequent than expected by chance in the 'Jura' (Figure 2). This finding is, however, confounded with the extensive storm damage area produced by storm Lothar (winter 1999) that 


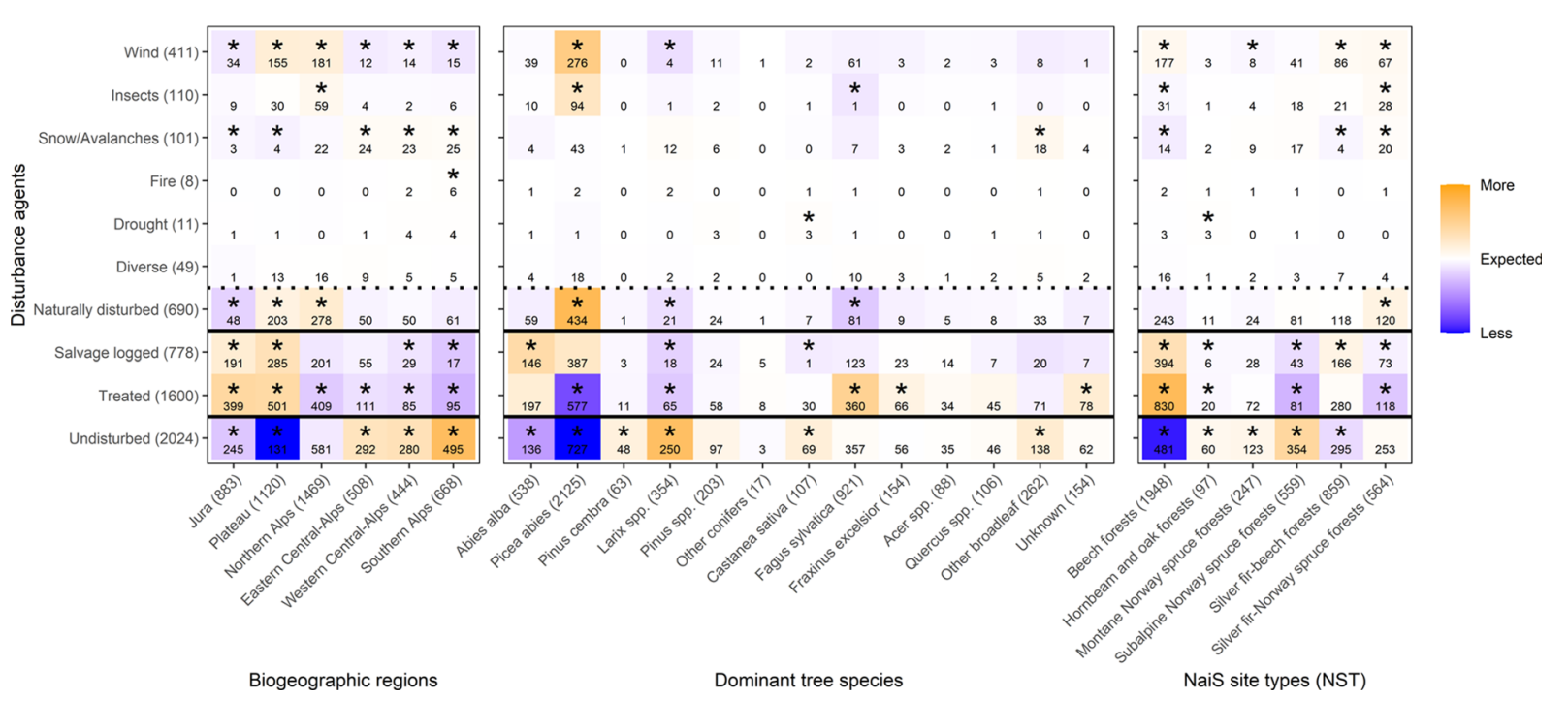

Figure 2. Matrix of different disturbances agents and biogeographic regions (left), dominant tree species (middle) and NaiS site types (right). The colours indicate more frequent (orange) or less frequent (blue) interactions than statistically expected. The asterisks indicated significant differences $(p<0.05$; Chi2-test) between expectations and observations. The numbers indicate the number of observations. 'Naturally disturbed' reflects the pooled data of the six different natural disturbance agents.

mainly affected the 'Plateau' and 'Northern Alps' and resulted to be by far the most impactful natural disturbance event during the observation period ( $8 \%$ of all NFI plots). The 'Northern Alps' were significantly more affected by bark beetles, while forest fires occurred significantly more often in the 'Southern Alps' (Figure 2). Storm Lothar also led to a strong synchronisation of wind and insect disturbed plots as over $85 \%$ of the wind affected sites were recorded in 1999 and $85 \%$ of the insect affected sites during the 5 years following the storm (2000-2005, Figure S2). As a side effect of this 'synchronisation' of wind and insect damage, our analysis becomes much more consistent as the time interval between disturbance event and NFI observation showed low variability and therefore regrowth and tree recruitment stages are comparable. NFI plots in the 'Jura' and 'Plateau' were significantly more often 'treated' and 'salvage logged' than the regions of the Alps (Figure 2).

Sample plots dominated by $P$. abies were overproportionally affected by natural disturbances (63\% of all disturbed plots), which especially holds for wind and insects ( $>80 \%$; Figure 2) primarily in the 'Plateau' and 'Northern Alps'. Plots dominated by C. sativa more often suffered from drought (Figure 2). In contrast, plots dominated by F. sylvatica or Larix spp. were significantly less often affected by any disturbances. Additionally, stands dominated by Pinus spp. (mostly Pinus sylvestris) were over-proportionally affected by drought in the dry valleys of the 'Western Central-Alps' but not nationwide $\left(X^{2}=7.3898, d f=1, p\right.$-value $=$ 0.00656). Sample plots dominated by $A$. alba were over proportionally often 'salvage logged', and plots dominated by F. sylvatica and $P$. abies were significantly more, respectively less often 'treated'.

Plots with a NST of silver fir-Norway spruce forests were significantly more often affected by disturbances than any other community, and in particular by wind, insects and snow (Figure 2). Wind also over-proportionally affected NSTs of beech and silver fir-beech forests, while drought over-proportionally disturbed plots with a NST of hornbeam and oak forests (Figure 2). More than $75 \%$ of the wind disturbed plots with a NST of beech forest were dominated by another tree species (mainly P. abies and, to a lesser degree, A. alba). In fact, $P$. abies dominated stands were significantly more often affected by wind disturbance when found on sites with NSTs dominated by broadleaves (for example, potential natural beech forests; $X^{2}=8.7242, \quad d f=1, \quad p$-value $\left.=0.00314\right)$. Beech forests and silver fir-beech forests were over proportionally 'treated' and 'salvage logged' and subsequently significantly less often 'undisturbed', while the opposite was true for Norway spruce forests (Figure 2). 


\section{Disturbance Effects on Species Composition}

Between 1995 and 2017, the total BA of Swiss forests, as well as the BA per ha, increased from $34.8 \mathrm{M} \mathrm{m}^{2}$ and $31.0 \mathrm{~m}^{2} \mathrm{ha}^{-1}$ to $37.5 \mathrm{M} \mathrm{m}^{2}$ and $32.7 \mathrm{~m}^{2} \mathrm{ha}^{-1}$, respectively. However, the subset of NFI plots used in our study showed a more pronounced BA increase of $+2.4 \mathrm{~m}^{2} \mathrm{ha}^{-1}$. This difference is explained by the fact that the NFI plots omitted in our analysis showed a decrease in BA $\left(-7.4 \mathrm{~m}^{2} \mathrm{ha}^{-1}\right)$ and represent most likely disturbed/damaged plots, but were removed from the dataset due to missing information on disturbance agents. The observed BA change mostly represented an increase of broadleaf trees $\left(+1.5 \mathrm{~m}^{2} \mathrm{ha}^{-}\right.$ $\left.{ }^{1},+14.8 \%\right)$, while coniferous trees remained almost constant $\left(+0.9 \mathrm{~m}^{2} \mathrm{ha}^{-1},+4.6 \%\right.$; Table $\left.\mathrm{s} 4\right)$ increasing the BA contribution of broadleaves by $2 \%$. If merely 'undisturbed' plots were considered, BA of both conifers and broadleaf species increased proportionally $(+31.4 \%$ for conifers and $+29.7 \%$ for broadleaves), but conifers were much more affected by natural disturbances than broadleaves ($39.4 \%$ for conifers and $-4.9 \%$ for broadleaves; Table S4). This shift from conifers towards broadleaves after natural disturbance events was particularly strong in the lowlands and decreased with elevation (Figure S3).

The two dominant natural disturbance agents (wind and insect outbreaks) mainly affected dense conifer stands dominated by $P$. abies $163 \%$ of disturbed plots), particularly in the 'Plateau' and the 'Northern Alps' (Figure 2), leading to a drastic reduction in BA of $P$. abies ( $-44 \%$; Table S5, Figure 3). Pinus spp. was the only taxon that decreased in overall BA and was especially affected by wind and drought disturbances (Table S5, Figure 3). The only broadleaf species showing a significant decrease in BA was $F$. sylvatica after windthrow. Additionally, C. sativa showed a tentative disturbance effect on BA after drought in the 'Southern Alps' (Table S6, Figure 3).

A detailed analysis of sites affected by wind or insect disturbances revealed that both, plots naturally dominated by $P$. abies (that is, NST of spruce forests) as well as plots naturally dominated by broadleaves showed a dramatic decrease of $P$. abies BA. However, the effect on $P$. abies was significantly stronger on sites naturally dominated by broadleaves ( $-56 \pm 4 \%$ for wind, $-37 \pm 9 \%$ for insect) than on sites with NST of spruce forest $(-21 \pm 7 \%$ for wind, $-24 \pm 14 \%$ for insects; Wilcoxon ranksum test with continuity correction $W=19,375$, $p<0.001$ for wind, $W=1719, p=0.04$ for insects; Figure 4).

In contrast to the 'naturally disturbed' plots, the 'undisturbed' plots (that is, no human intervention or natural disturbance) showed a significant increase in BA of all taxa except Pinus spp. (Figure 3). 'Treated' plots showed an increase in BA of A. alba, $P$. abies, Larix spp., other conifers, Acer spp. and Fraxinus spp. and a decrease for F. sylvatica (Figure 3). On 'salvage logged' plots, the BA of F. sylvatica increased and Pinus spp. decreased.

\section{Post-disturbance Vegetation Trajectories}

Sapling density was higher in NFI4 than in NFI2 (+ 29.7\%, Table S7) while the density of pole-stage trees was lower $(-5.6 \%$, Table S8). Surprisingly, the number of plots without any saplings increased from 20 to $34 \%$ while the number of plots without pole-stage individuals decreased from 57 to $47 \%$ (Tables S7-S8). On 'naturally disturbed' plots mean sapling-density was reduced, and pole-stage-density increased compared to 'undisturbed' plots (Tables S7-S8). Sapling density was dominated by broadleaves $(87 \%)$ while the pole-stage density was evenly distributed between conifers and broadleaves (Figures S7-8). 'Undisturbed' plots showed a slight decrease in saplings recruitment of conifers $(-2.5 \%)$ and an increase for broadleaves $(+10.7 \%)$, but conifers were much more successful in prevailing into the pole-stage recruitment $(+16.3 \%)$ than broadleaves $(-18.6 \%$, Tables S7S8). Both 'salvage logged' and 'treated' plots showed an increase in sapling recruitment for both conifers and broadleaves but broadleaves were more successful in the pole-stage recruitment than conifers, especially on 'salvage logged' plots (Tables S7-S8). 'Naturally disturbed' plots showed an increase of sapling recruitment in conifers $(+60 \%)$ while the pole-stage recruitment was dominated by broadleaves $(+81.6 \%)$.

Due to the relatively small sampling area and the associated extrapolation to the hectare, data on tree recruitment were highly stochastic and variable. As a result, only very few significant disturbance-induced and species-specific changes in vegetation trajectories could be detected. On PNCs of broadleaves that were mostly stocked with conifers, wind disturbance led to a shift of the vegetation trajectory towards more broad leaf recruitment over the last 20 years (Figure 4). No such shift in tree recruitment was observed on wind-disturbed, and insect-attacked sites naturally dominated by spruce (Figure 4). Additionally, P. abies was the only species showing a significant negative effect of silvi- 

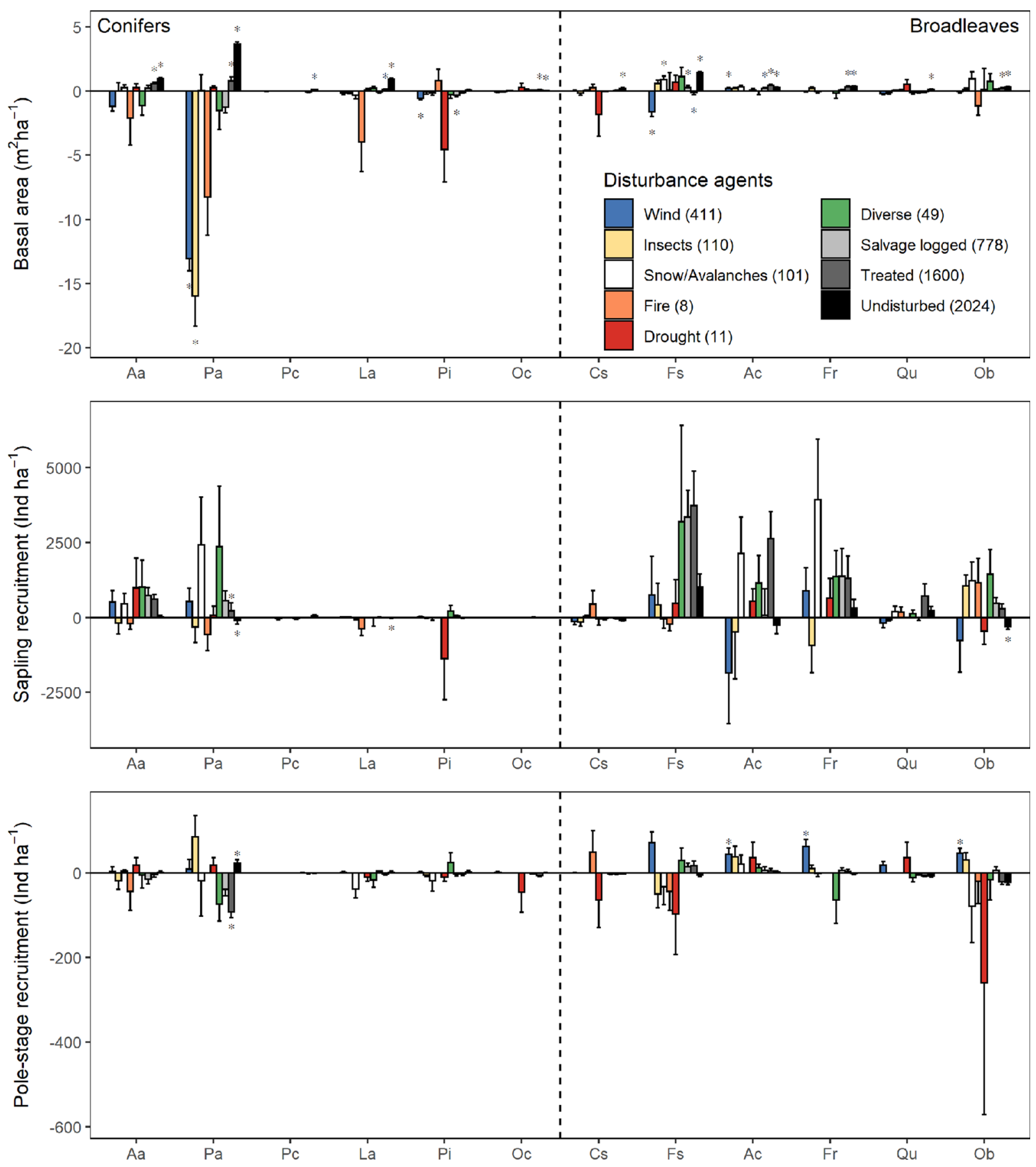

Figure 3. Change in basal area $\left(\mathrm{m}^{2} \mathrm{ha}^{-1}\right.$; top), sapling recruitment (stems ha ${ }^{-1}$ with height $>10 \mathrm{~cm}$ and DBH $<4 \mathrm{~cm}$; middle) and pole-stage recruitment (stems ha ${ }^{-1}$ with DBH $4-11.9 \mathrm{~cm}$; bottom) between NFI2 and NFI4 records on sample plots affected by different disturbances agents. Number is bracket indicate the number of NFI plots per disturbance category. Coloured bars indicate the mean, black bars the standard errors. Asterisks mark significant changes (pairwiseWilcoxon with Holm correction, $p<0.05)$. Aa $=$ Abies alba, $\mathrm{Pa}=$ Picea abies, $\mathrm{Pc}=$ Pinus cembra, La $=$ Larix spp., Pi $=$ Pinus spp., Oc = other conifers, Cs $=$ Castanea sativa, Fs $=$ Fagus sylvatica, Ac $=$ Acer spp., Fr $=$ Fraxinus spp., Qu = Quercus spp., $\mathrm{Ob}=$ other broadleaves.

cultural treatment on pole-stage recruitment. In sites affected by drought, recruitment by Pinus ssp. decreased in favour of Quercus spp., especially in the
'Western Central-Alps' while in the 'Southern Alps', the recruitment of C. sativa decreased on drought-prone sites (Tables S9-S12; Figure 3). 

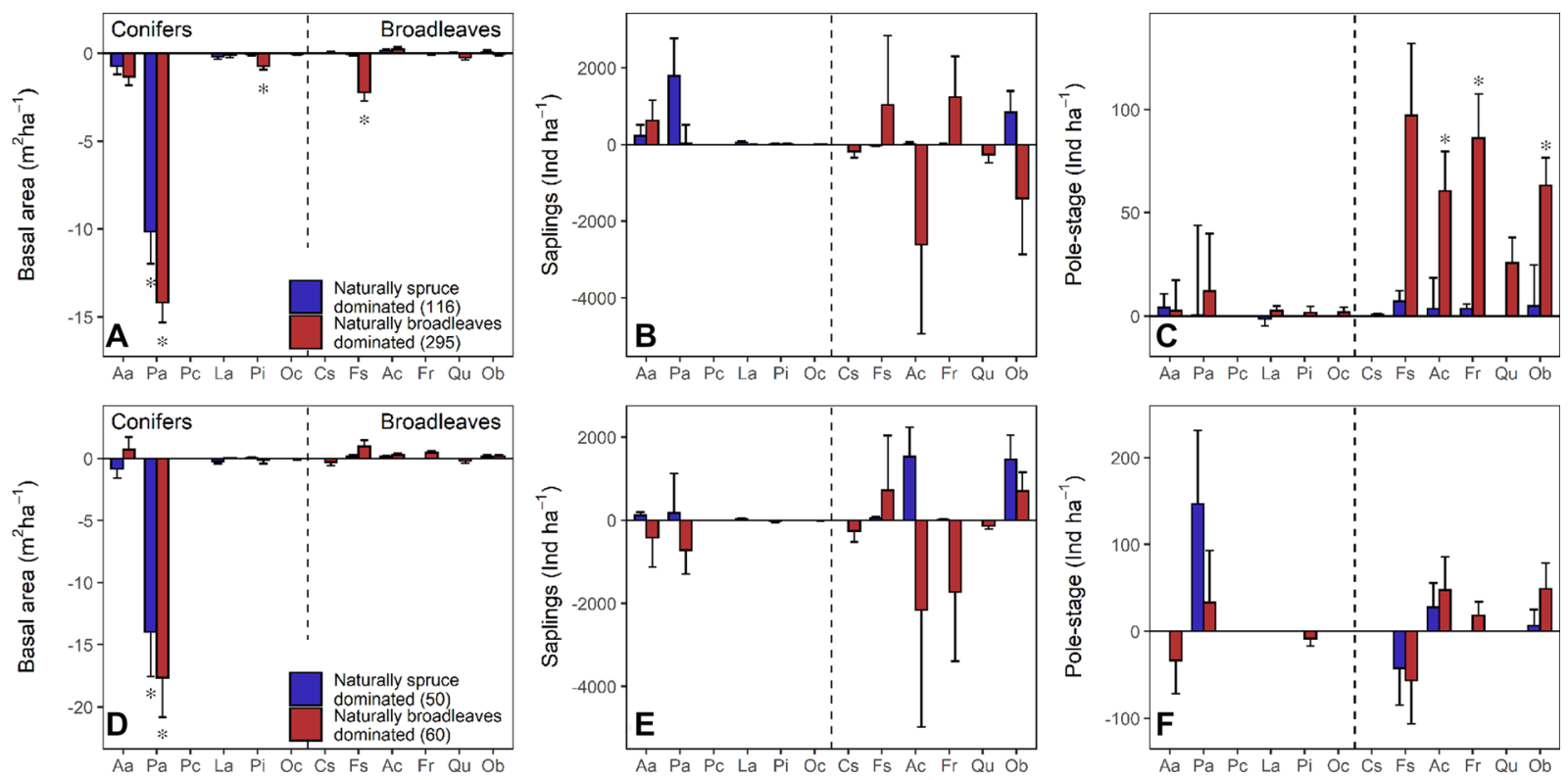

Figure 4. Change in basal area $\left(\mathrm{m}^{2} \mathrm{ha}^{-1} ; \mathrm{a}, \mathrm{d}\right)$, sapling recruitment (stems ha ${ }^{-1}$ with height $>10 \mathrm{~cm}$ and $\mathrm{DBH}<=3.9 \mathrm{~cm} ; \mathrm{b}, \mathrm{e}$ ) and pole-stage recruitment (stems ha ${ }^{-1}$ with DBH $4-11.9 \mathrm{~cm}$; c,f) between NFI2 and NFI4 records on NFI sample plots affected by wind $(\mathrm{a}, \mathrm{b}, \mathrm{c})$ and insect disturbance $(\mathrm{d}, \mathrm{e}, \mathrm{f})$ grouped into plots naturally dominated by spruce (blue, montane/sub-alpine Norway spruce forests and Silver fir-Norway spruce forests) and naturally dominated by broadleaves (red). Aa = Abies alba, Pa = Picea abies, Pc $=$ Pinus cembra, La = Larix spp., Pi $=$ Pinus spp., Oc $=$ other conifers, Cs = Castanea sativa, Fs = Fagus sylvatica, Ac = Acer spp., Fr = Fraxinus spp., Qu = Quercus spp., Ob = other broadleaves.

Castanea sativa was also the only species showing a consistent decrease in tree recruitment (saplings and pole-stage trees) across all plots with the notable exception of post-fire tree recruitment (Tables S11-S12; Figure 3).

\section{Discussion}

\section{Canopy Disturbances as Catalysts of Forest Vegetation Shifts}

Over the last 25 years, the Swiss forests showed a shift from conifer towards a higher proportion of broadleaf species especially at lower elevations (Figure S3). This life form shift was mainly driven by extensive natural canopy disturbances ( $>0.1$ ha), or a combination of the natural and anthropogenic disturbance ('salvage logged'), as the conifers-broadleaves ratio did not change in 'treated' and 'undisturbed' plots. Additionally, in the warmest and driest regions of Switzerland, comparisons indicate that extreme droughts led to diverging tree species compositions affecting mostly chestnut groves and oak-pine forests.

Although part of this general shift in taxa composition of the tree recruitment might reflect successional dynamics indicated by an increase in fastgrowing and more site-specific species (for exam- ple, Acer spp., Fraxinus spp. and other broadleaves). our data indicate that this also reflects a lasting transition towards a new climax state dominated by broadleaves (that is, mostly beech).

\section{Anthropogenic Disturbances (Forest Management)}

Anthropogenic disturbances ('salvage logged' and 'treated') are unevenly distributed across regions and taxa but seem mostly correspondent to two factors: Accessibility and phytosanitary instances due to insect outbreaks. Both 'salvage logged' and 'treated' plots are over-proportionally located in the 'Jura' and 'Plateau' as well as in NST of beech forests and plots dominated by $F$. sylvatica, which are mainly located in these two biogeographic regions. Forest in these regions is highly accessibility due to a dense system of forest roads at widely unproblematic terrain and stand productivity favouring more intensive silvicultural interventions. 'Salvage logged' plots were also over proportionally practiced in stands dominated by A. alba and consequently in NST of Silver fir-Beech forest and likely related to the containment and prevention of insect outbreaks as well as good accessibility. 


\section{Fatal Attraction: P. abies Outside of Their Natural Range}

Although the overall contribution to BA of most species only slightly changed $( \pm 0.7 \%)$ between 1995 and 2017, a considerable if not dramatic change was observed in $P$. abies $(-2.9 \%)$, and stands dominated by $P$. abies were confirmed to be especially susceptible to certain natural disturbances $(62 \%$ of all natural disturbance events), which resulted in a shift towards more broadleaf species. This is not surprising when considering the general susceptibility of $P$. abies to both windthrows (for example, Hanewinkel and others 2011) and the European spruce bark beetle (Ips typographus; for example, Wermelinger 2004; Faccoli and Bernardinelli 2014), including the interaction of beetle attacks in spruce forests weakened by wind disturbance and/or prolonged drought (Stadelmann and others 2013; De Groot and others 2018; Dobor and others 2020).

In our study large-scale wind damage in P. abies stands occurred predominantly during the Lothar storm (1999), which mostly affected forests at low elevations within the range of the natural beech and silver fir-beech communities. No major storm occurred during the observation period in montane and subalpine Norway spruce forests. In mountain spruce forests affected by Vivian (storm of February 1990 at higher elevations, predominantly in the Central Alpine valleys) the post-disturbance regeneration trajectories were dominated by $P$. abies (Schönenberger 2002). In contrast, in the Lothar-affected lowlands and foothills of the PreAlps, where P. abies is mostly out of the natural range as it was frequently planted in the past and promoted in the frame of adopted German silvicultural systems (Bürgi and Schuler 2003), the post-disturbance trajectories indicate a decrease in $P$. abies. This pattern was additionally reinforced by the abundant bark beetle outbreaks that occurred on plots previously affected by wind disturbance during the heatwave in summer 2003 (Forster and Meier 2010; Stadelmann and others 2014).

Our data on pole-stage recruitment suggest that on low elevation sites, where forests are naturally dominated by broadleaves, disturbances significantly altered tree species compositions away from $P$. abies (and conifers in general) towards more broadleaf species. The shift towards more broadleaves was stronger after wind than insect disturbance. Bark beetles usually mainly attack trees older than 50 years, leaving younger trees healthy (Wermelinger 2004) and therefore limiting the potential for a dramatic shift in vegetation trajec- tories. Nevertheless, salvage logging to control bark beetle infestations and intensified harvests of $P$. abies to avoid financial loss due to expected further lowering of wood prices likely amplified this trend (Kläy 2015). As the most influential disturbance events happened around 15-20 years ago the shift in vegetation trajectories was mostly visible in the well-established pole-stage that is nowadays dominated by broadleaves. This indicates that, at low elevations, broadleaf species are competitively superior to $P$. abies, as had been demonstrated in post-windthrow patches (Kramer and others 2014). The increased reliance on natural regeneration in the second half of the twentieth century (Burgi 1999) has also contributed to their recent re-expansion. Additionally, at lower elevations foresters started to transition forests away from $P$. abies by species regulation in the juvenile phase (up to thickets) and through targeted thinning, explaining the observed negative effect of silvicultural treatment on pole-stage recruitment of $P$. abies. Because most future climate change scenarios predict an increased frequency of extreme weather events such as large storm systems, prolonged droughts and heatwaves, linked disturbances (for example, Seidl and others 2017) need to be considered. Insect attacks likely increase, as wind-disturbed and climatically stressed trees, become more susceptible (Brandl and others 2020) and warmer temperatures stimulate bark beetle population dynamics resulting in more generations and higher densities during one season (Stadelmann and others 2013; Jakoby and others 2016). At higher elevations, disturbances did not seem to negatively affect the recruitment of conifers both after wind and insect disturbances. In these cooler forest habitats, the tree regeneration is dominated by direct ingrowth of the stand-forming coniferous species. This is in line with findings of Kramer and others (2014) on regeneration in gaps produced by windthrow across Switzerland. Therefore, while $P$. abies is still increasing in BA and pole-stage recruitment on 'undisturbed' sites, the expected increase in natural disturbances in the frame of the ongoing climate change might accelerate the tree species shift of these stands in the future.

\section{Impressive Though Rare: Fire and Drought}

In contrast to damage by wind and insect outbreaks, other disturbance agents or extreme events such as fire and drought were rarely observed during the study period and affected only a small proportion of the Swiss forest area $(<0.2 \%$ of 
plots) mostly located in the warmest ('Southern Alps') and driest biogeographic Swiss regions ('Western Central-Alps'). In the dry valleys of the 'Western Central-Alps' drought has negatively affected P. sylvestris that has for long dominated slopes at low elevation due to traditional land-use practices (pasture and litter collection; Gimmi and others 2010) towards the dry limits of forest growth (Etzold and others 2019). Land-use change in the past decades in combination with repeated extreme drought events increased tree mortality (for example, Rigling and others 2013) and benefit the more drought-resistant and shade-tolerant downy oak (Q. pubescens). Combined drought-shade effects to drought-tolerant $P$. sylvestris (Niinemets and Valladares 2006), hampers successful recruitment (Bachofen and others 2019). Similar transitions from pines to oaks are reported for dry regions in Italy (Vacchiano and Motta 2015) and Spain (for example, Zavala and others 2000; Galiano and others 2010; Carnicer and others 2014; MoránLópez and others 2014).

In the 'Southern Alps' drought mostly affected forests dominated by C. sativa. The chestnut groves in southern Switzerland are the result of a longterm land use practice aimed at producing both fruits for the self-sustainment and wood (Krebs and others 2012), which encouraged the chestnut cultivation at the limits of the tree and in some cases even at the edge of its fundamental niche (Muster and others 2007). Similar to the pine-dominated forests in the Valais, the suspension of any management input made the chestnut groves particularly susceptible to the colonisation by other more site-specific tree species, exposing the light-demanding $C$. sativa trees to competition, climatic stress and specific diseases (Conedera and others 2001). On the driest and most exposed sites, this resulted also in an enhanced summer drought susceptibility as revealed by the 2003 summer drought and heatwave (Conedera and others 2009). All this induces a shift towards the NST, that is, corresponding to beech on rich sites at higher elevations and broadleaf mixed forests dominated by lime (Tilia spp.) as well as maple trees (Acer spp.) in the lowlands (Conedera and others 2000; Muster and others 2007). Fire displays, on contrary, the opposite effect by enhancing the recruitment of the disturbance-adapted $C$. sativa that profits from its extreme resprouting capacity and outcompetes other fire-sensitive broadleaves (Delarze and others 1992), including shade tolerant and slow growing invasive evergreen species such as the native Ilex aquifolium or the neophytitic Trachycarpus fortunei and Prunus laurocerasus (Grund and others 2005), but not fast growing and invasive neophytic pioneer tree species such as Ailanthus altissima or Paulownia tomentosa (Maringer and others 2012).

So far, both drought and fire affected the forest dynamics trajectory only in NFI plots in the warmest and driest parts of the country that are dominated by certain species as a result of centurylong management effects (that is, C. sativa and $P$. sylvestris) that partially grow at their ecological limits. The question arises how disturbances may affect the most widespread forest types such as spruce and beech forests in the future. Conspicuous drought damage in both beech and spruce forests during the recent summer drought periods (2018, 2019; Schuldt and others 2020) suggests that drought may assume a central role in shaping future tree species compositions in Swiss Forests. Evidence of forest fires impacting usually fireavoiding forest types such as beech stands is also increasing in recent decades (Maringer and others 2016).

\section{Limits of the Study}

In this study, we used the data collected on revisited plots of the Swiss forest inventory. Besides the great advantage of the long time span of the observations (up to 25 years) and the permanent character of the plots, the used data present also some limits. The shift of the survey from a periodic three-years lasting survey (NFI2) to a continuous, nine-years lasting field activity (NFI4) implies that the period of observation may vary by up to eight years among plots. In addition, the survey protocol of the recruitment slightly changed between the two inventories and the retrospective approach in reconstructing and assessing the disturbances that occurred on each plot may represent a source of imprecision.

Systematic samples such as the NFI produce representative results in terms of quantitative rankings. However, important small-scale phenomenon such as the local spread of pioneer species (Maringer and others 2012; Conedera and others 2018), the dynamic of rare species or the study of detailed post-disturbance ecological processes require targeted and species-specific approaches (for example, Wohlgemuth and others 2002, 2018; Allen and others 2010; Moser and others 2010; Rigling and others 2013; Maringer and others 2020; Schuldt and others 2020). 


\section{ConClusions}

Most future climate scenarios predict warmer and drier conditions across Switzerland and Europe in general (Zubler and others 2014) and an increased risk of prolonged droughts (Spinoni and others 2018), forest fires (Pezzatti and others 2016) and large storms (Collins and others 2019). However, while models often predict dramatic changes in forests with ongoing climate change (for example, Lindner and others 2014; Dyderski and others 2018), representative studies observe no or only slow transitions (for example, Gehrig-Fasel and others 2007; Lenoir and others 2010b; Küchler and others 2015). Despite the limits of the present approach, we detected natural and anthropogenic disturbance as a major trigger of tree species shifts in Swiss forests in the current global change context. At present, post-disturbance tree species shifts predominantly occur where dominant species have been cultivated out of its natural range due to economic reasons (that is, P. abies in the lowland of the Plateau). Additionally, forests seem increasingly at risk in hitherto traditional ranges of management (that is, widespread pure pine stands at low elevations in the Valais or the chestnut groves in the Southern Alps). Overall, our data suggest that the forest trajectory after a disturbance favours recruitment of species of the natural forest vegetation. In particular, in disturbed P. abies stands at the low-lands, broadleaf species regenerate most successfully, while in $P$. abies stands at higher elevations, direct regrowth of this and other coniferous species prevails. Undisturbed forest stands, on contrary, persisted in their species composition, and the constrained tree recruitment under the canopy was mostly comprised of the species dominating the stand. Tree regeneration under dense canopies is always sparse, and only a few species can build up an abundant 'seedling bank' in a closed and shady stand (Grubb 1977; Savage and others 1996). Most species rather regenerate in pulses realised in canopy gaps (Zackrisson and others 1995; Jentsch and White 2019). In a small gap, however, the chance that seeds from new species arrive during the window of opportunity for the seedling establishment is a stochastic event, and most gaps will be filled with seedlings from the already present dominant species (Moser and others 2010). Therefore, in undisturbed forests, the dominating tree species rather than the abiotic conditions are driving species selection. Largerscale disturbances, on the other hand, seem to level the playing field allowing more species to establish and favour those (among which many oppor- tunistic ones) that are adapted to the current environmental conditions and can increase resistance against future disturbances (for example, repeated insect outbreaks; Sommerfeld and others 2020). Larger-scale disturbances might therefore act as essential catalysts to enable/accelerate the transition of forest ecosystems in adaptation to changing environmental conditions (Brice and others 2019, 2020).

\section{FUNDING}

Open Access funding provided by Lib4RI - Library for the Research Institutes within the ETH Domain: Eawag, Empa, PSI \& WSL.

\section{OPEN ACCESS}

This article is licensed under a Creative Commons Attribution 4.0 International License, which permits use, sharing, adaptation, distribution and reproduction in any medium or format, as long as you give appropriate credit to the original author(s) and the source, provide a link to the Creative Commons licence, and indicate if changes were made. The images or other third party material in this article are included in the article's Creative Commons licence, unless indicated otherwise in a credit line to the material. If material is not included in the article's Creative Commons licence and your intended use is not permitted by statutory regulation or exceeds the permitted use, you will need to obtain permission directly from the copyright holder. To view a copy of this licence, visit $h$ ttp://creativecommons.org/licenses/by/4.0/.

\section{DATA AVAILABILITY}

The data and R-scripts used in this manuscript are stored in the EnviDat repository (https://doi.org/ 10.16904/envidat.219). The raw data from the Swiss NFI can be provided free of charge within the scope of a contractual agreement (http://www.lfi. ch/dienstleist/daten-en.php).

\section{REFERENCES}

Allen CD, Breshears DD, McDowell NG. 2015. On underestimation of global vulnerability to tree mortality and forest dieoff from hotter drought in the Anthropocene. Ecosphere 6:155.

Allen CD, Macalady AK, Chenchouni H, Bachelet D, McDowell N, Vennetier M, Kitzberger T, Rigling A, Breshears DD, Hogg ET. 2010. A global overview of drought and heat-induced tree mortality reveals emerging climate change risks for forests. Forest Ecology and Management 259:660-684. 
Ascoli D, Vacchiano G, Turco M, Conedera M, Drobyshev I, Maringer J, Motta R, Hacket-Pain A. 2017. Inter-annual and decadal changes in teleconnections drive continental-scale synchronization of tree reproduction. Nature communications 8:1-9.

Bachofen C, Wohlgemuth T, Moser B. 2019. Biomass partitioning in a future dry and CO 2 enriched climate: Shading aggravates drought effects in Scots pine but not European black pine seedlings. Journal of Applied Ecology 56:866-879.

Bertrand R, Lenoir J, Piedallu C, Riofrio-Dillon G, de Ruffray P, Vidal C, Pierrat JC, Gegout JC. 2011. Changes in plant community composition lag behind climate warming in lowland forests. Nature 479:517-520.

Bertrand R, Riofrío-Dillon G, Lenoir J, Drapier J, de Ruffray P, Gégout JC, Loreau M. 2016. Ecological constraints increase the climatic debt in forests. Nature communications 7.

Bolte A, Hilbrig L, Grundmann BM, Roloff A. 2014. Understory dynamics after disturbance accelerate succession from spruce to beech-dominated forest-the Siggaboda case study. Annals of forest science 71:139-147.

Brandl S, Paul C, Knoke T, Falk W. 2020. The influence of climate and management on survival probability for Germany's most important tree species. Forest Ecology and Management 458:117652.

Brändli U-B, Hägeli M. 2019. Swiss NFI at a Glance. Swiss National Forest Inventory-Methods and Models of the Fourth Assessment: Springer. pp 3-35.

Brändli UB, Abegg M, Allgaier Leuch B. 2020a. Schweizerisches Landesforstinventar. Ergebnisse der vierten Erhebung 20092017. Birmensdorf, Bern: Eidgenössische Forschungsanstalt für Wald, Schnee und Landschaft WSL, Bundesamt für Umwelt BAFU.

Brändli UB, Abegg M, Düggelin C. 2020b. Biologische Vielfalt. Brändli UB, Abegg $M$, Allgaier Leuch B editors. Schweizerisches Landesforstinventar: Ergebnisse der vierten Erhebung 2009-2017. Birmensdorf, Bern: Eidgenössische Forschungsanstalt für Wald, Schnee und Landschaft WSL, Bundesamt für Umwelt, BAFU, p189-238.

Brang P, Spathelf P, Larsen JB, Bauhus J, Boncčina A, Chauvin C, Drössler L, García-Güemes C, Heiri C, Kerr G. 2014. Suitability of close-to-nature silviculture for adapting temperate European forests to climate change. Forestry: An International Journal of Forest Research 87: 492-503.

Brice M-H, Cazelles K, Legendre P, Fortin M-J. 2019. Disturbances amplify tree community responses to climate change in the temperate-boreal ecotone. Global Ecology and Biogeography 28:1668-1681.

Brice M-H, Vissault S, Vieira W, Gravel D, Legendre P, Fortin MJ. 2020. Moderate disturbances accelerate forest transition dynamics under climate change in the temperate-boreal ecotone of eastern North America. Global Change Biology 26:4418-4435.

Burgi M. 1999. A case study of forest change in the Swiss lowlands. Landscape Ecology 14:567-575.

Bürgi M, Schuler A. 2003. Driving forces of forest management-an analysis of regeneration practices in the forests of the Swiss Central Plateau during the 19th and 20th century. Forest Ecology and Management 176:173-183.

Carnicer J, Coll M, Pons X, Ninyerola M, Vayreda J, Peñuelas J. 2014. Large-scale recruitment limitation in $M$ editerranean pines: the role of Q uercus ilex and forest successional advance as key regional drivers. Global Ecology and Biogeography $23: 371-384$
Cioldi F, Brändli UB, Didion M, Fischer C, Ginzler C, Herold A, Huber M, Thürig E. 2020. Waldresourcen. Abegg M, AllgaierLeuch B editors. Schweizerisches Landesforstinventar. Ergebnisse der vierten Erhebung 2009-2017. Birmensdorf, Bern: Eidgenössische Forschungsanstalt für Wald, Schnee und Landschat WSL; Bundesamt fur Umwelt BAFU, p35-119.

Civantos E, Thuiller W, Maiorano L, Guisan A, Araujo MB. 2012. Potential Impacts of Climate Change on Ecosystem Services in Europe: The Case of Pest Control by Vertebrates. Bioscience 62:658-666.

Collins M, Sutherland M, Bouwer L, Cheong S-M, Frölicher T, Jacot Des Combes H, Koll Roxy M, Losada I, McInnes K, Ratter B, Rivera-Arriaga E, Susanto RD, Swingedouw D, Tibig L. 2019. Extremes, Abrupt Changes and Managing Risk. Pörtner H-O, Roberts DC, Masson-Delmotte V, Zhai P, Tignor M, Poloczanska E, Mintenbeck K, Alegría A, Nicolai M, Okem A, Petzold J, Rama B, Weyer NM editors. IPCC Special Report on the Ocean and Cryosphere in a Changing Climate.

Conedera M, Barthold F, Torriani D, Pezzatti G. 2009. Drought sensitivity of Castanea sativa: case study of summer 2003 in the Southern Alps. I European Congress on Chestnut-Castanea 2009(866):297-302.

Conedera M, Stanga P, Lischer C, Stöckli V. 2000. Competition and dynamics in abandoned chestnut orchards in southern Switzerland. Ecologia mediterranea 26:101-112.

Conedera M, Stanga P, Oester B, Bachmann P. 2001. Different post-culture dynamics in abandoned chestnut orchards and coppices. For Snow Landsc Res 76:487-492.

Conedera M, Wohlgemuth T, Tanadini M, Pezzatti GB. 2018. Drivers of broadleaved evergreen species spread into deciduous forests in the southern Swiss Alps. Regional Environmental Change 18:425-436.

Copenhaver-Parry PE, Carroll CJ, Martin PH, Talluto MV. 2020. Multi-scale integration of tree recruitment and range dynamics in a changing climate. Global Ecology and Biogeography 29:102-116.

De Groot M, Ogris N, Kobler A. 2018. The effects of a large-scale ice storm event on the drivers of bark beetle outbreaks and associated management practices. Forest Ecology and Management 408:195-201.

Delarze R, Caldelari D, Hainard P. 1992. Effects of Fire on Forest Dynamics in Southern Switzerland. Journal of Vegetation Science 3:55-60.

Dobor L, Hlásny T, Rammer W, Zimová S, Barka I, Seidl R. 2020. Spatial configuration matters when removing windfelled trees to manage bark beetle disturbances in Central European forest landscapes. Journal of Environmental Management 254:109792.

Düggelin C, Keller M. 2017. Schweizerisches Landesforstinventar, Feldaufnahme-Anleitung 2017. Forschungsanstalt für Wald, Schnee und Landschaft, Birmensdorf: Eidg.

Dyderski MK, Paź S, Frelich LE, Jagodziński AM. 2018. How much does climate change threaten European forest tree species distributions? Global Change Biology 24:1150-1163.

Etzold S, Ziemińska K, Rohner B, Bottero A, Bose AK, Ruehr NK, Zingg A, Rigling A. 2019. One century of forest monitoring data in Switzerland reveals species-and site-specific trends of climate-induced tree mortality. Frontiers in Plant Science 10:307.

Faccoli M, Bernardinelli I. 2014. Composition and elevation of spruce forests affect susceptibility to bark beetle attacks: Implications for forest management. Forests 5:88-102. 
Fischer C, Traub B. 2019. Swiss National Forest InventoryMethods and Models of the Fourth Assessment: Springer.

Forster B, Meier F. 2010. Surm, Witterung und Borkenkäfen. Risikomanagement im Forstschutz. Eidg. Forschungsanstalt für Wlad SuLW editor. Birmensdorf: Eidg. Forschungsanstalt für Wlad, Schnee und Landschaft WSL.

Frehner ARGE, M, Dionea SA, IWA - Wald und Landschaft AG. 2020. NaiS-LFI - Zuordnung der LFI-Stichprobenpunkte zu Waldgesellschaften. Auftrag des Bundesamt für Umwelt BAFU: Erläuternder Schlussbericht. p p68.

Frey H, Frehner M, Burnand J, Carraro G, Rutishauser U. 2021. Zur Entstehung der NaiS-Standortstypen. Schweizerische Zeitschrift für Forstwesen 172.

Galiano L, Martínez-Vilalta J, Lloret F. 2010. Drought-induced multifactor decline of Scots pine in the Pyrenees and potential vegetation change by the expansion of co-occurring oak species. Ecosystems 13:978-991.

Gehrig-Fasel J, Guisan A, Zimmermann NE. 2007. Tree line shifts in the Swiss Alps: Climate change or land abandonment? Journal of Vegetation Science 18:571-582.

Gimmi U, Wohlgemuth T, Rigling A, Hoffmann CW, Bürgi M. 2010. Land-use and climate change effects in forest compositional trajectories in a dry Central-Alpine valley. Annals of forest science 67:701.

Gonseth Y, Wohlgemuth T, Sansonnens B, Buttler A. 2001. Die biogeographischen regionen der Schweiz. Umwelt Materialien: Erläuterungen und Einteilungsstandard. p 137.

Grubb PJ. 1977. The maintenance of species-richness in plant communities: the importance of the regeneration niche. Biological Reviews 52:107-145.

Grund K, Conedera M, Schröder H, Walther G-R. 2005. The role of fire in the invasion process of evergreen broad-leaved species. Basic and Applied Ecology 6:47-56.

Grundmann BM, Bolte A, Bonn S, Roloff A. 2011. Impact of climatic variation on growth of Fagus sylvatica and Picea abies in Southern Sweden. Scandinavian Journal of Forest Research 26:64-71.

Hanewinkel M, Hummel S, Albrecht A. 2011. Assessing natural hazards in forestry for risk management: a review. European Journal of Forest Research 130:329-351.

Hernández L, Cañellas I, Alberdi I, Torres I, Montes F. 2014. Assessing changes in species distribution from sequential large-scale forest inventories. Annals of forest science 71:161171.

Jakoby O, Stadelmann G, Lischke H, Wermelinger B. 2016. Borkenkäfer und Befallsdisposition der Fichte im Klimawandel. Wald im Klimawandel. Grundlagen für Aaptionsstrategien. Bundesamt für Umwelt BAFU Bern: 247-264.

Jandl R, Spathelf P, Bolte A, Prescott CE. 2019. Forest adaptation to climate change-is non-management an option? Annals of forest science $76: 48$.

Jentsch A, von Heßberg A. 2019. Die Störungsregime und Klimaextreme der Vegetationszonen der Erde. T. W, Jentsch A, Seidl R editors. Störungsökologie. Bern: Verlag Haupt, p4574.

Jentsch A, White P. 2019. A theory of pulse dynamics and disturbance in ecology. Ecology 100:e02734.

Jump AS, Hunt JM, Peñuelas J. 2007. Climate relationships of growth and establishment across the altitudinal range of Fagus sylvatica in the Montseny Mountains, northeast Spain. Ecoscience 14:507-518.
Kassambara A. 2020. rstatix: Pipe-Friendly Framework for Basic Statistical Tests.

Kläy M. 2015. Wirtschaftliche Lage der Forstbetriebe. Rigling A, Schaffner HP editors. Waldbericht 2015 - Zustand und Nutzung des Schweizer Waldes. Bern: Bundesamt für Umwelt, pl06-107.

Kramer K, Brang P, Bachofen H, Bugmann H, Wohlgemuth T. 2014. Site factors are more important than salvage logging for tree regeneration after wind disturbance in Central European forests. Forest Ecology and Management 331:116-128.

Krebs P, Koutsias N, Conedera M. 2012. Modelling the ecocultural niche of giant chestnut trees: new insights into land use history in southern Switzerland through distribution analysis of a living heritage. Journal of Historical Geography 38:372-386.

Küchler M, Küchler H, Bedolla A, Wohlgemuth T. 2015. Response of Swiss forests to management and climate change in the last 60 years. Annals of forest science 72:311-320.

Lanz A, Fischer C, Abegg M. 2019. Sampling design and estimation procedures. Swiss National Forest Inventory-methods and models of the fourth assessment: Springer, p39-92.

Lenoir J, Bertrand R, Comte L, Bourgeaud L, Hattab T, Murienne J, Grenouillet G. 2020. Species better track climate warming in the oceans than on land. Nature ecology $\delta$ evolution 4:1044-1059.

Lenoir J, Gegout JC, Dupouey JL, Bert D, Svenning JC. 2010. Forest plant community changes during 1989-2007 in response to climate warming in the Jura Mountains (France and Switzerland). Journal of Vegetation Science 21:949-964.

Lenoir J, Gegout JC, Guisan A, Vittoz P, Wohlgemuth T, Zimmermann NE, Dullinger S, Pauli H, Willner W, Svenning JC. 2010. Going against the flow: potential mechanisms for unexpected downslope range shifts in a warming climate. Ecography 33:295-303.

Lenoir J, Gégout JC, Marquet PA, De Ruffray P, Brisse H. 2008. A significant upward shift in plant species optimum elevation during the 20th century. Science 320:1768-1771.

Liang Y, Duveneck MJ, Gustafson EJ, Serra-Diaz JM, Thompson JR. 2018. How disturbance, competition, and dispersal interact to prevent tree range boundaries from keeping pace with climate change. Global Change Biology 24:e335-e351.

Lindner M, Fitzgerald JB, Zimmermann NE, Reyer C, Delzon S, van der Maaten E, Schelhaas M-J, Lasch P, Eggers J, van der Maaten-Theunissen M. 2014. Climate change and European forests: what do we know, what are the uncertainties, and what are the implications for forest management? Journal of Environmental Management 146:69-83.

Maringer J, Conedera M, Ascoli D, Schmatz DR, Wohlgemuth T. 2016. Resilience of European beech forests (Fagus sylvatica L.) after fire in a global change context. International Journal of Wildland Fire 25:699-710.

Maringer J, Wohlgemuth T, Hacket-Pain A, Ascoli D, Berretti R, Conedera M. 2020. Drivers of persistent post-fire recruitment in European beech forests. Science of the Total Environment 699:134006.

Maringer J, Wohlgemuth T, Neff C, Pezzatti GB, Conedera M. 2012. Post-fire spread of alien plant species in a mixed broadleaved forest of the Insubric region. Flora-Morphology, Distribution, Functional Ecology of Plants 207:19-29.

McDowell NG, Allen CD, Anderson-Teixeira K, Aukema BH, Bond-Lamberty B, Chini L, Clark JS, Dietze M, Grossiord C, Hanbury-Brown A, Hurtt GC, Jackson RB, Johnson DJ, 
Kueppers L, Lichstein JW, Ogle K, Poulter B, Pugh TAM, Seidl R, Turner MG, Uriarte M, Walker AP, Xu C. 2020. Pervasive shifts in forest dynamics in a changing world. Science 368: eaaz9463.

MeteoSwiss. 2020. The Climate of Switzerland.

Millar CI, Stephenson NL, Stephens SL. 2007. Climate change and forests of the future: managing in the face of uncertainty. Ecological Applications 17:2145-2151.

Morán-López T, Poyatos R, Llorens P, Sabaté S. 2014. Effects of past growth trends and current water use strategies on Scots pine and pubescent oak drought sensitivity. European Journal of Forest Research 133:369-382.

Moser B, Temperli C, Schneiter G, Wohlgemuth T. 2010. Potential shift in tree species composition after interaction of fire and drought in the Central Alps. European Journal of Forest Research 129:625-633.

Muster S, Elsenbeer H, Conedera M. 2007. Small-scale effects of historical land use and topography on post-cultural tree species composition in an Alpine valley in southern Switzerland. Landscape Ecology 22:1187-1199.

Niinemets Ü, Valladares F. 2006. Tolerance to shade, drought, and waterlogging of temperate Northern Hemisphere trees and shrubs. Ecological Monographs 76:521-547.

Nikolova PS, Rohner B, Zell J, Brang P. 2019. Tree species dynamics in Swiss forests as affected by site, stand and management: A retrospective analysis. Forest Ecology and Management 448:278-293.

Pecl GT, Araújo MB, Bell JD, Blanchard J, Bonebrake TC, Chen I-C, Clark TD, Colwell RK, Danielsen F, Evengård B. 2017. Biodiversity redistribution under climate change: Impacts on ecosystems and human well-being. Science 355: eaai9214.

Penuelas J, Boada M. 2003. A global change-induced biome shift in the Montseny mountains (NE Spain). Global Change Biology 9:131-140.

Pereira HM, Leadley PW, Proenca V, Alkemade R, Scharlemann JPW, Fernandez-Manjarres JF, Araujo MB, Balvanera P, Biggs R, Cheung WWL, Chini L, Cooper HD, Gilman EL, Guenette S, Hurtt GC, Huntington HP, Mace GM, Oberdorff T, Revenga C, Rodrigues P, Scholes RJ, Sumaila UR, Walpole M. 2010. Scenarios for Global Biodiversity in the 21st Century. Science 330:1496-1501.

Pezzatti G, De Angelis A, Conedera M, Pluess A, Augustin S, Brang P. 2016. Potenzielle Entwicklung der Waldbrandgefahr im Klimawandel. Bern: Wald im Klimawandel. Grundlagen für Adaptationsstrategien. Bundesamt für Umwelt BAFU. pp 223-245.

R Core Team. 2020. R: A Language and Environment for Statistical Computing. Vienna, Austria: R Foundation for Statistical Computing.

Rigling A, Bigler C, Eilmann B, Feldmeyer-Christe E, Gimmi U, Ginzler C, Graf U, Mayer P, Vacchiano G, Weber P. 2013. Driving factors of a vegetation shift from Scots pine to pubescent oak in dry Alpine forests. Global Change Biology 19:229-240.

Savage M, Brown PM, Feddema J. 1996. The role of climate in a pine forest regeneration pulse in the southwestern United States. Ecoscience 3:310-318.

Scherrer D, Massy S, Meier S, Vittoz P, Guisan A. 2017. Assessing and predicting shifts in mountain forest composition across 25 years of climate change. Diversity and Distributions 23:517-528.
Scherrer D, Vitasse Y, Guisan A, Wohlgemuth T, Lischke H. 2020. Competition and demography rather than dispersal limitation slow down upward shifts of trees' upper elevation limits in the Alps. Journal of Ecology n/a.

Schönenberger W. 2002. Windthrow research after the 1990 storm Vivian in Switzerland: objectives, study sites, and projects. Forest Snow and Landscape Research 77:2.

Schuldt B, Buras A, Arend M, Vitasse Y, Beierkuhnlein C, Damm A, Gharun M, Grams TE, Hauck M, Hajek P. 2020. A first assessment of the impact of the extreme 2018 summer drought on Central European forests. Basic and Applied Ecology.

Seidl R, Thom D, Kautz M, Martin-Benito D, Peltoniemi M, Vacchiano G, Wild J, Ascoli D, Petr M, Honkaniemi J. 2017. Forest disturbances under climate change. Nature climate change 7:395-402.

Shi H, Zhou Q, Xie F, He N, He R, Zhang K, Zhang Q, Dang H. 2020. Disparity in elevational shifts of upper species limits in response to recent climate warming in the Qinling Mountains, North-central China. Science of the Total Environment 706:135718.

Sommerfeld A, Rammer W, Heurich M, Hilmers T, Müller J, Seidl R. 2020. Do bark beetle outbreaks amplify or dampen future bark beetle disturbances in Central Europe? Journal of Ecology n/a.

Spathelf P, Bolte A, van der Maaten E. 2015. Is Close-to-Nature Silviculture (CNS) an adequate concept to adapt forests to climate change. Landbauforschung 65:161-170.

Spinoni J, Vogt JV, Naumann G, Barbosa P, Dosio A. 2018. Will drought events become more frequent and severe in Europe? International Journal of Climatology 38:1718-1736.

Stadelmann G, Bugmann H, Wermelinger B, Bigler C. 2014. Spatial interactions between storm damage and subsequent infestations by the European spruce bark beetle. Forest Ecology and Management 318:167-174.

Stadelmann G, Bugmann H, Wermelinger B, Meier F, Bigler C. 2013. A predictive framework to assess spatio-temporal variability of infestations by the European spruce bark beetle. Ecography 36:1208-1217.

Stierlin H-R. 1994. Schweizerisches Landesforstinventar: Anleitung für die Feldaufnahmen der Erhebung 1993-1995: Eidgenössische Forschungsanstalt für Wald, Schnee und Landschaft.

Svenning JC, Skov F. 2007. Could the tree diversity pattern in Europe be generated by postglacial dispersal limitation? Ecology Letters 10:453-460.

Talluto MV, Boulangeat I, Vissault S, Thuiller W, Gravel D. 2017. Extinction debt and colonization credit delay range shifts of eastern North American trees. Nature ecology \& evolution 1:0182.

Vacchiano G, Motta R. 2015. An improved species distribution model for Scots pine and downy oak under future climate change in the NW Italian Alps. Annals of forest science 72:321-334.

Wermelinger B. 2004. Ecology and management of the spruce bark beetle Ips typographus-a review of recent research. Forest Ecology and Management 202:67-82.

Wickham H, François R, Henry L, Müller K. 2020. dplyr: A Grammar of Data Manipulation.

Wohlgemuth T, Doublet V, Nussbaumer C, Feichtinger L, Rigling A. 2018. Baumartenwechsel in den Walliser Waldföhrenwäl- 
dern verstärkt nach grossen Störungen. Schweizerische Zeitschrift für Forstwesen 169:260-268.

Wohlgemuth T, Kull P, Wüthrich H. 2002. Disturbance of microsites and early tree regeneration after windthrow in Swiss mountain forests due to the winter storm Vivian 1990. For. Snow Landsc. Res 77:2.

Zackrisson O, Nilsson M-C, Steijlen I, Hornberg G. 1995. Regeneration pulses and climate-vegetation interactions in nonpyrogenic boreal Scots pine stands. Journal of Ecology: 469-483.

Zavala M, Espelta J, Retana J. 2000. Constraints and trade-offs in Mediterranean plant communities: the case of holm oakAleppo pine forests. The Botanical Review 66:119-149.

Zubler EM, Fischer AM, Liniger MA, Croci-Maspoli M, Scherrer SC, Appenzeller C. 2014. Localized climate change scenarios of mean temperature and precipitation over Switzerland. Climatic Change 125:237-252. 